\title{
IMPACTS OF URBANISATION LEVEL AND DISTANCE FROM POTENTIAL NATURAL MOSQUITO BREEDING HABITATS ON THE ABUNDANCE OF CANINE DIROFILARIOSIS
}

\author{
Attila TRÁJeR ${ }^{1,2 *}$, Antal RenGeI ${ }^{3}$, Kinga FARKAS-IVÁNYI ${ }^{4}$ and Ákos BeDE-FAZEKAS ${ }^{5,6}$ \\ ${ }^{1}$ Department of Limnology, University of Pannonia, Egyetem utca 10, H-8200 Veszprém, \\ Hungary; ${ }^{2}$ MTA-PE Limnoecology Research Group, Veszprém, Hungary; ${ }^{3}$ Small Animal \\ Clinic of Szeged, Szeged, Hungary; ${ }^{4}$ Institute for Soil Sciences and Agricultural Chemistry, \\ Centre for Agricultural Research, Hungarian Academy of Sciences, Budapest, Hungary; \\ ${ }^{5}$ Institute of Ecology and Botany, Centre for Ecology, Hungarian Academy of Sciences, \\ Vácrátót, Hungary; ${ }^{6}$ Department of Garden and Open Space Design, Faculty of \\ Landscape Architecture and Urbanism, Szent István University, Budapest, Hungary
}

(Received 10 October 2015; accepted 4 May 2016)

\begin{abstract}
Dirofilariosis is an emerging mosquito-borne veterinary and medical problem in the Northern hemisphere. The ecological investigation of 56 canine dirofilariosis cases in new endemic locations was performed in Szeged, Hungary. The aim was to analyse the influence of the spatial patterns of dog abundance and the potential mosquito breeding habitats on the spatial occurrence patterns of dirofilariosis in the city of Szeged. The limnoecological characterisation was based on the fluvial habitat classification of Amoros of natural water bodies; the built environment was evaluated using the UrbanisationScore urbanisation intensity measuring software. Dirofilaria immitis accounted for $51 \%$ and D. repens for $34.3 \%$ of the dirofilariosis cases, and in $20 \%$ of the cases only the Knott's test was positive. It was concluded that most of the cases were related to locations with a medium to high urbanisation index, although the proximity of mosquito-bearing waters also played an important role in the observed spatial infection patterns. We found that the distance from potential mosquito habitats and the urbanisation intensity determine the abundance of dirofilariosis in urban environments.
\end{abstract}

Key words: Dirofilaria immitis, Dirofilaria repens, urbanisation intensity, Amoros classification

Dirofilariosis caused by Dirofilaria immitis and D. repens is one of the most important emerging parasitic, mosquito-borne diseases in the oceanic and temperate climate areas of Europe (Raccurt, 1999; Pampiglione et al., 2001) and North America with serious veterinary and human medical consequences (Macêdo et al., 1998; Pampiglione et al., 1999; Traversa et al., 2010b). In the Americas,

\footnotetext{
*Corresponding author; E-mail: atrajer@gmail.com; Phone: 0036 (20) 330-9186
} 
Iran, Turkey and Australia D. immitis is the sole causative agent of canine dirofilariosis, while in China, North Central Europe and South Africa D. repens is the parasite responsible for canine dirofilariosis. In several countries of South Europe and in Hungary both $D$. immitis and D. repens cause infection in dogs (Simón et al., 2012). Heartworm disease is an emerging parasitosis among dogs in Europe. Within a single decade (from 2001 to 2011), canine dirofilariosis became endemic in seven European countries (Albania, Bulgaria, Croatia, the Czech Republic, Hungary, Romania and Serbia) and in a Russian federal state (Morchón et al., 2012).

In primary hosts such as Canis lupus familiaris (Traversa et al., 2010a) and even in Canis lupus (Pascucci et al., 2007), D. immitis is one of the causative agents of parasitic cardiopulmonary disease which can culminate in heart failure and death (Macêdo et al., 1998). In addition, Capillaria aerophila, Aelurostrongylus abstrusus (in cats) and Angiostrongylus vasorum are also important cardiopulmonary nematodes in certain areas of Europe (Di Cesare et al., 2011).

The first imported dirofilariosis case caused by D. immitis was reported from Hungary in 1982 (Boros et al., 1982) and the first autochthonous case was observed only in 2007 (Jacsó et al., 2009). Serological studies conducted in Hungary demonstrated that about $2.4 \%$ of dogs are infected by D. immitis (Farkas et al., 2014).

Dirofilaria repens, which is a common and persistent parasitic agent in dogs of Hungary (Jacsó, 2014), has greater human health importance. In the period of 2001-2013 alone, a total of 88 human cases were recorded in Hungary, and in 35 cases eye involvement was observed (Kucsera et al., 2014). Cases involving human eye infection were reported from the city studied in this work (Szeged, Hungary) as well (Szénási et al., 2008).

The most important vectors of Dirofilaria species are different mosquitoes from the genera Aedes, Anopheles, Culex, Culiseta, and Coquillettidia (Morchón et al., 2012), and the species responsible for transmitting the infection vary from area to area: Ae. scapularis, Ae. taeniorhynchus and Cx. quinquefasciatus in Brazil (Labarthe et al., 1998), Ae. albopictus, Ae. caspius, An. maculipennis and Cq. richiardii in Italy (Cancrini et al., 1995, 2003, 2006), Ae. albopictus and Cx. quinquefasciatus in China, Cx. tritaeniorhynchus and Ae. albopictus in Japan (Tesh, 1989) are the notable vectors of D. immitis. In Italy, Ae. albopictus and members of the $C x$. pipiens complex are the most prominent natural vectors of $D$. repens (Cancrini et al., 2003, 2007). The species of the $C x$. pipiens complex are regarded as the dominant vectors of dirofilariosis in several countries of Europe, e.g. in Spain (Morchón et al., 2007), Italy (Cancrini et al., 2006), Turkey (Yildirim et al., 2011) and Hungary (Zittra et al., 2015). Morchón et al. (2012) published a detailed review about the potential mosquito vectors of animal dirofilariosis in Europe. 
Many studies have analysed dirofilariosis caused by $D$. immitis Leidy (1856) from the veterinary (Webber and Hawking, 1955; Newton and Wright, 1956), human medical (Ciferri, 1982; Muro et al., 1999; Pampiglione et al., 2009), parasitological and vector-epidemiological (Kartman, 1953; Ludlam et al., 1970; Labarthe et al., 1998; Cancrini et al., 2003), geographical (Bowman et al., 2009) and even climatic (Genchi et al., 2009, 2011) points of view. Despite the fact that in human $D$. immitis cases the parasites do not develop into adults in most cases, immature worms have been rarely found in humans (Muro et al., 1999). As regards geographical distribution, $D$. immitis occasionally causes human infections in the Mediterranean region of the European Union (Jelinek et al., 1996; Muro et al., 1999), and human dirofilariosis cases predominantly occur in the Americas, Japan, and Australia. Several human medical aspects of dirofilariosis caused by $D$. immitis have been described in the literature (Moorhouse, 1978; Merrill et al., 1980; Ciferri, 1982; Theis et al., 2001; Simón et al., 2005). Human dirofilariosis cases are predominantly caused by $D$. repens in most countries of Eurasia (Simón et al., 2012).

The treatment of infected dogs can lead to severe and potentially lethal complications such as thromboembolism after a massive chemical intervention (Rawlings et al., 1993). The preventive treatment of dogs could be an important element of the control of dirofilariosis as it was proposed for the dog populations of the Balkan Peninsula (Tasić-Otašević et al., 2015). Prevention relies on the characterisation of risk factors and the identification of vulnerable animal populations. It has been suggested that the spatial abundance patterns of domesticated hosts (dogs) and Dirofilaria vectors determine the abundance of dirofilariosis in an urbanised area. Our aim was to study the influence of urbanisation level and proximity to standing waters on the spatial distribution of dirofilariosis caused by the two Dirofilaria species in Szeged, Hungary.

\section{Materials and methods}

Szeged is the county seat of Csongrád County, located near the Hungarian-Serbian border in the southern part of the Hungarian Great Plain at the confluence of the Maros and Tisza rivers (Fig. 1). The environment of Szeged is rich in lakes and other standing waters while the area of the city comprises at least 20 lakes and 6 oxbows. The second largest river of Hungary, the river Tisza, crosses the city. In contrast with the high density of waters, the area of Szeged is highly urbanised. The number of permanent inhabitants was 161,921 in 2011 (KSH, 2013) and the city has an extensive agglomeration as it is the regional centre of the Southern Great Plain. Owing to the above-mentioned circumstances Szeged is an ideal location for analysing the influence of urbanisation level and proximity to standing waters on the spatial distribution of canine dirofilariosis. 


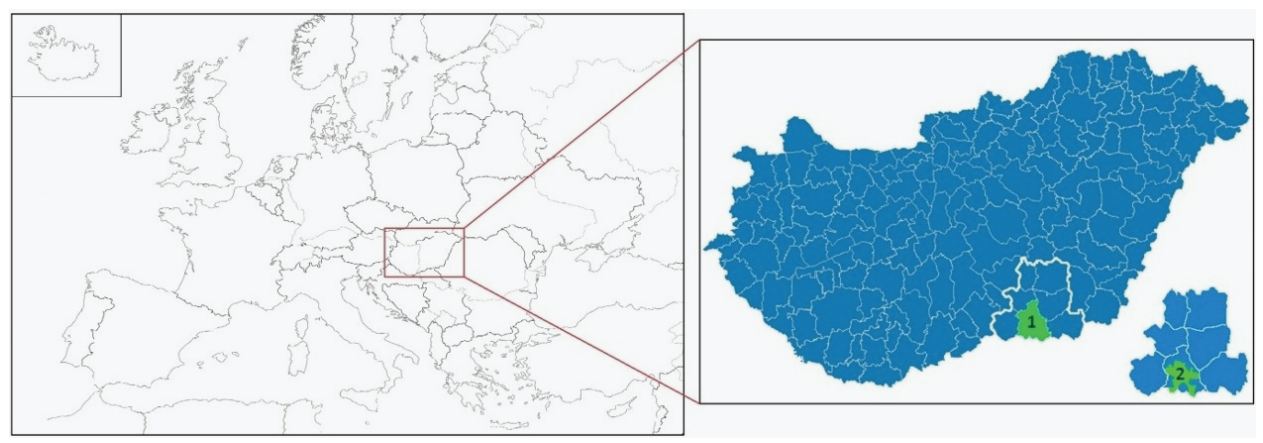

Fig. 1. Hungary within Europe, the map of the Hungarian subregions (NUTS 4 regions). A separate map shows the Szeged subregion within Csongrád County (No. 1, green in the county map) and the boundaries of Szeged (No. 2, green in the subregion map)

A total of 56 canine dirofilariosis cases were investigated in the study; all examined between August 2013 and September 2014 at the Pet Ambulance in Szeged. Blood samples were tested by the following methods: modified Knott's method, Dirofilaria (Ag) ELISA tests (Witness ${ }^{\circledR}$ Dirofilaria Test, SNAP ${ }^{\circledR} 4 \mathrm{Dx}^{\circledR}$ Plus Test). In addition, in 35 cases PCR was used for the specific detection of $D$. immitis and D. repens as described by Casiraghi et al. (2006). In 11 cases PCR analysis was not performed. Adult helminth specimens were photographed during the dissection (Fig. 2).

The basic concept of calculating the spatial abundance of canine dirofilariosis was that the spatial abundance of dirofilariosis cases in an urbanised area is determined primarily by the encounter of Dirofilaria vectors and the susceptible organisms, in this case the dogs. Equation 1 shows the general form of the compound probability of these components. The compound probability of an independent event is:

Equation 1: $\mathrm{P}(\mathrm{AB})=\mathrm{P}(\mathrm{A}) \times \mathrm{P}(\mathrm{B})$,

where $\mathrm{P}(\mathrm{AB})$ is the compound probability,

$\mathrm{P}(\mathrm{A})$ is the probability of event $\mathrm{A}$, and

$\mathrm{P}(\mathrm{B})$ is the probability of event $\mathrm{B}$.

The compound probability of two independent events is the product of the probabilities of the distance from potential mosquito habitats and the abundance of dogs according to the urbanisation intensity of an area (Equation 2):

Equation 2: $\mathrm{P}_{\mathrm{e}}=\mathrm{D}_{\mathrm{m}} \times \mathrm{A}_{\mathrm{UI}}$,

where $\mathrm{P}_{\mathrm{e}}$ is the compound probability of the encounter with infected mosquitoes,

$\mathrm{D}_{\mathrm{m}}$ is the distance from potential mosquito habitats, and

$\mathrm{A}_{\mathrm{UI}}$ is the abundance of dogs according to the urbanisation intensity of an area. 


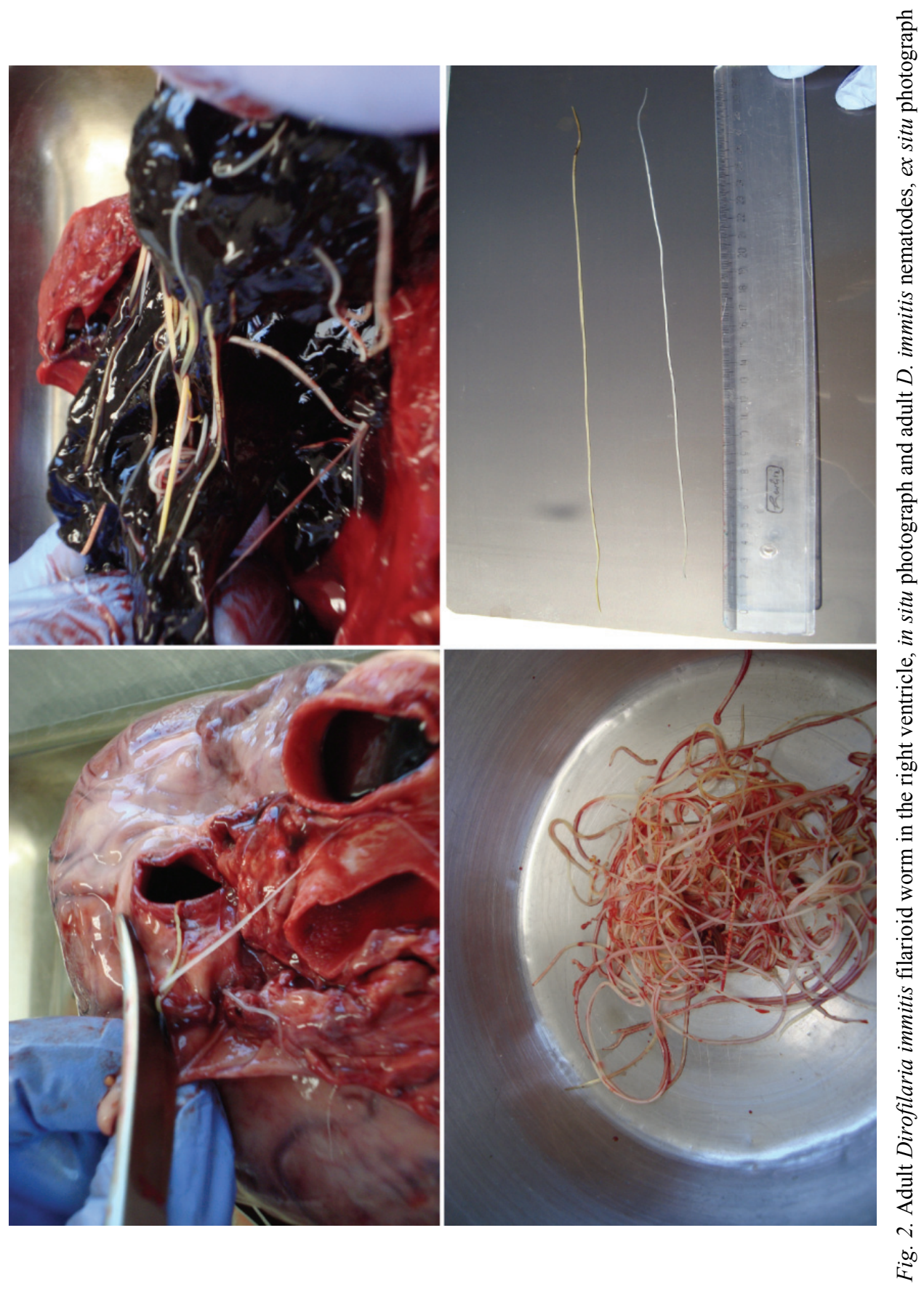




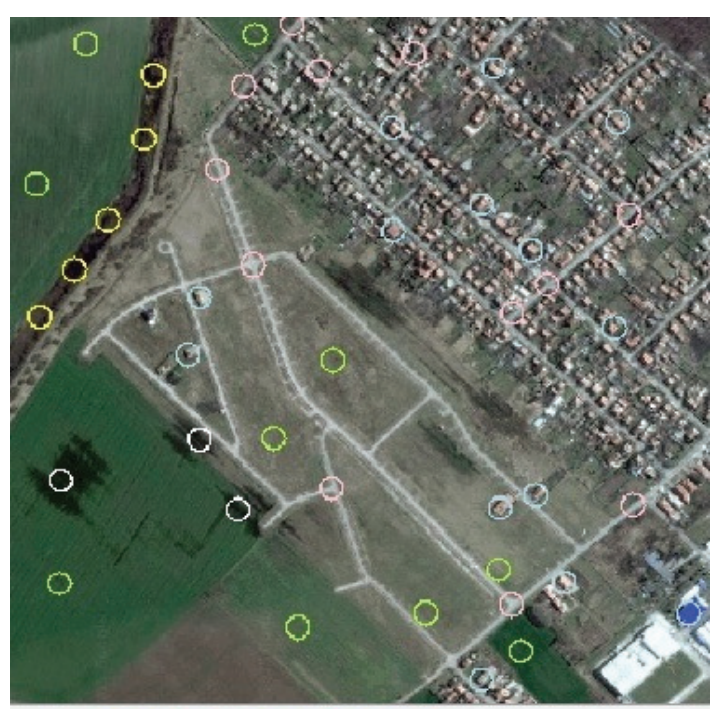

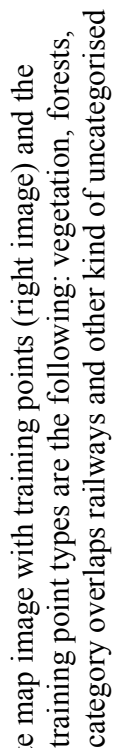

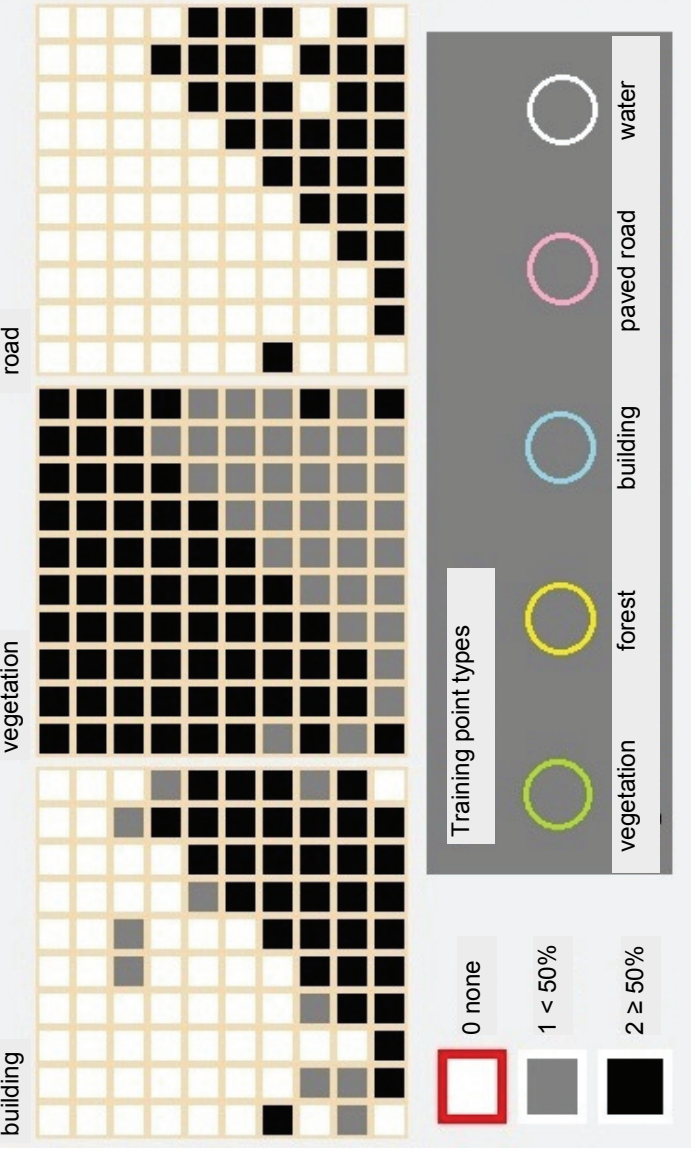

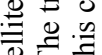

क

o 0

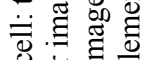

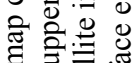

娄焉

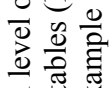

을

을

㐘

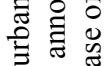

渮.

흔

旅

를. 这

西

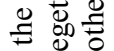

웅

:

视

of

的春

is

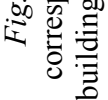




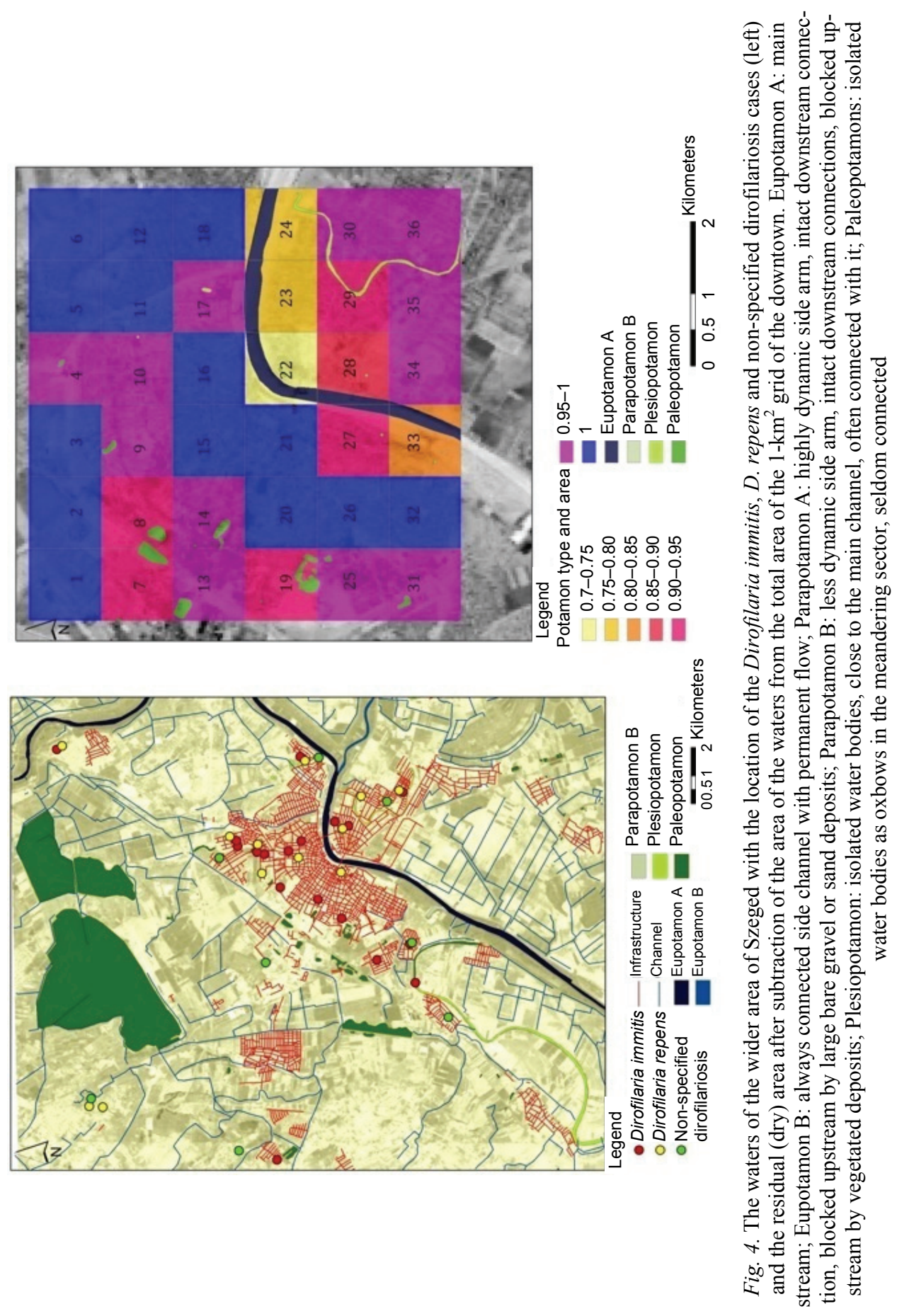


The maximum $P_{e}$ value was expressed as 1 . The other values were calculated as the ratio of the maximum encounter probability.

River stream types are often characterised by certain species of the fauna and the vegetation, and water catchment areas provide excellent habitats for mosquitoes, such as e.g. Aedes vexans (Kenyeres and Tóth, 2008). The habitat characteristics of fluvial ecosystems can be analysed by the different level of the spatio-temporal hierarchy. The qualities of macro-, meso- and micro-bedforms form a functional unit which can be characterised by the qualities of bedform size, time-span of existence and superposition of bedforms in time (Jackson, 1975). The use of river system hierarchies in applied river research has been supported by several authors (Frissell et al., 1986; Amoros et al., 1987; Kern, 1994; Newbury, 1996; Petts and Amoros, 1996). The limnoecological characterisation of water bodies in this study was primarily based on the functional unit theory of Amoros et al. (1987). The identification of ephemeral (existing only for a short period) technotelma waters (small water bodies in man-made objects such as water barrels, car tires or jars) was not possible. As a working hypothesis, it was assumed that the spatial distribution of major water bodies and wetlands may have the most notable influence on the size of mosquito populations and it has a relatively stable spatial pattern. The identified types of (major) aquatic habitats were extracted from the Google Earth ${ }^{\mathrm{TM}}$ satellite map of the studied area.

To calculate the distance of the case sites from the potential mosquito habitats, first of all we defined and categorised the meaning of the "potential mosquito habitat' according to the following categories: (1) floodplain, floodplain forest; (2) swamp, reeds, wetland; (3) oxbow, artificial lake.

If a lake has well-visible marsh, shallow fringing marsh, fringing marsh swamp or swamp forest margin vegetation, the proximal margin of the wetland vegetation was used as the proximate of the potential mosquito habitat. The 'functional sets' concept (Amoros et al., 1987) and the definitions are those used for the Austrian section of the Danube (Hohensinner et al., 2011) with minor modifications. The potential mosquito habitats are derived from the 'functional sets' concept of Amoros et al. (1987), with the exception of one habitat, the 'artificial lake'; however, artificial waters provide the same conditions for mosquitoes as the appropriate natural waters.

The determined potamonic (derived from the ancient Greek potamos

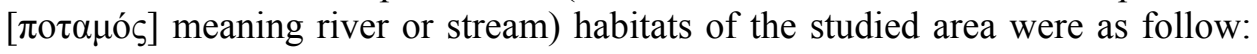
eupotamon A (main stream), eupotamon B (permanently connected side channels, with permanent flow), parapotamon A (highly dynamic side arms, intact downstream connection, blocked upstream by bare gravel/sand deposits), parapotamon B (less dynamic side arms, intact downstream connections, blocked upstream by vegetated deposits), plesiopotamon (isolated water bodies, close to the main channel, often connected) and paleopotamon (not or seldom connected, iso- 
lated water bodies). Table 1 contains the descriptions of the characteristic features of different potama.

Table 1

Definitions of stream types according to Amoros et al. (1987)*

\begin{tabular}{llcc}
\hline Stream types & \multicolumn{1}{c}{ Definitions } & \multicolumn{1}{c}{ Sediment } & Mean flow velocity \\
\hline Eupotamon A & Main stream & $\begin{array}{l}\text { cobbles, major } \\
\text { gravels }\end{array}$ & $3 \mathrm{~m} / \mathrm{s}<$ \\
Eupotamon B & $\begin{array}{l}\text { Always connected side channels, } \\
\text { with permanent flow }\end{array}$ & gravels & $2-2.9 \mathrm{~m} / \mathrm{s}$ \\
Parapotamon A & $\begin{array}{l}\text { Highly dynamic side arms, intact } \\
\text { downstream connection, blocked } \\
\text { upstream by bare gravel/sand deposits }\end{array}$ & gravel, sand & $0.3-1.9 \mathrm{~m} / \mathrm{s}$ \\
Parapotamon B & $\begin{array}{l}\text { Less dynamic side arms, intact down- } \\
\text { stream connections, blocked upstream } \\
\text { by vegetated deposits }\end{array}$ & $\begin{array}{l}\text { fine grains } \\
\text { Isolated water bodies, close to the } \\
\text { main channel, often connected }\end{array}$ & sand, silt, mud \\
Plesiopotamon & $\begin{array}{l}\text { Isolated water bodies (oxbows } \\
\text { in the meandering sector), } \\
\text { seldom connected }\end{array}$ & $0.005-0.14 \mathrm{~m} / \mathrm{s}$ \\
Paleopotamon & silt, mud & $0.005 \mathrm{~m} / \mathrm{s}>$ \\
\hline
\end{tabular}

*The characteristic sediments and the approximate mean flow velocity values were added to the table

The data of Tóth (2004) and Tóth and Kenyeres (2012) covering three decades countrywide revealed that swamp-type natural standing waters are the most frequent (34\% of the total collecting sites) habitats of mosquitoes, although shallow lakes are also important (19\%). In case of the candidate vector of Dirofilaria species, the members of the Cx. pipiens complex, $48 \%$ of the collected larvae were found in shallow lakes and natural swamp waters. In the analysis the distance between the case site and the nearest point of the potential mosquito habitat was used.

The simple two-sample $t$-test was performed using VassarStats: Website for Statistical Computation (Lowry, 2004). The graphs were constructed in Microsoft Office Excel 2010. The georeferencing of the Google Earth map source was performed by using the topographic maps of Hungary in the period of World War II (Tímár et al., 2008), which is a digital and georeferred map publication in ArcGIS 10.0, using WGS-84 surface, UTM-34N co-ordinate system.

To quantify the degree of habitat urbanisation the Urbanisation Score software (Seress et al., 2011; Czúni et al., 2012; Gábor et al., 2014) was applied, which uses only publicly available satellite imagery from GoogleMaps, and the scoring approach introduced by Liker et al. (2008) was used. The Urbanisation 
Score software was developed in the Image Processing Laboratory at the University of Pannonia. The software generates semi-automated scores of habitat urbanisation. This application downloads an image of $1 \mathrm{~km}^{2}$ area around a selected location, then divides it into $100 \times 100 \mathrm{~m}$ cells, and scores the abundance of vegetation, buildings and paved surfaces in each cell. These scores are then used for calculating landscape-cover variables which are then combined by Principal Component Analysis (PCA) into a score of urbanisation for each area. 'Urbanisation scores' are suitable for objectively expressing an area's level of habitat urbanisation, thereby ranking study sites along an urbanisation gradient. The steps of the analysis are as follow: (1) the software downloads the maps from GoogleMaps according to the given geographical co-ordinates; (2) the user select 'training points' in each map which represent the different surface types (buildings, vegetations, roads, waters; Fig. 3); (3) the software calculates the landscape variables for each area, which is followed by PCA. The software uses the following landscape variables: number of cells with high building density and number of cells with high vegetation density ( $>50 \%$ cover; range: $0-100)$, number of cells with paved surface (range: $0-100$ ), mean building density score and mean vegetation density score (range: $0-2$ ). For each study area, the calculated scores for the abundance of the above-listed landscape variables are displayed for each $100 \times 100 \mathrm{~m}$ cell. It is important to note that after the overview of the primary results the user can manually overwrite the software-generated cell scores in any image cell, changing the landscape category if it is necessary. After the manual correction of some image cell scores, urbanisation scores can be recalculated by re-running the PCA.

The method was successfully used by some authors (Bókony et al., 2010, $2012 a, 2012 b$; Zhang et al., 2011). In the present work, the centres of the streets of the case sites (hereinafter: 'case sites') were used as the location of the cases to protect the privacy rights of the dog owners. This compromise can cause some inaccuracy in the calculation, but for example the length of the streets of Szeged is negligible compared to the generally used $1-\mathrm{km}^{2}$ grid of the software. Urbanisation level was calculated at grids which overlap the investigated dirofilariosis case sites in Szeged and some close peri-urban sites (the towns Kiskundorozsma, Szatymaz and Algyö). Urbanisation level values were also calculated at two central downtown locations in Szeged - as the samples of the most urbanised areas and two floodplain forests of the river Maros - as the samples of highly natural areas - close to the city. These four control sites were selected to gain comparable results in the PCA of our study (defining the most extreme points of the coordinate system). 


\section{Results}

PCR was performed in 35 out of the 56 cases. Dirofilaria immitis alone was detected in 18 , while $D$. repens in 12 cases from the blood samples. In five cases the presence of co-infection with the two Dirofilaria species was detected. In 11 cases PCR analysis was not performed, but the presence of a Dirofilaria pathogen was confirmed in the blood samples. Dirofilariosis cases accumulate in the pericentre districts of Szeged. Surprisingly, some of the cases were reported from the downtown or panel block districts. Four main aquatic habitats can be found in the environment of Szeged, the plesiopotamon, paleopotamon, parapotamon B and eupotamon A/B types according to the Amoros classification system (Fig. 4, right). Riverbank characterisation showed that paleopotamon and plesiopotamon riverbed types dominate the aquatic habitats of the area, although a substantial number of channels are also notable. Minor lakes can be found almost only in the east district of the city and major sodic lakes can be found close to the north-western districts. In total value, paleopotamonic waters are the most notable aquatic habitats within the studied grid (Fig. 4, left). Overall, 56.5\% of the infections occurred between 263 and $524 \mathrm{~m}$ from the case sites and $87.5 \%$ of the cases occurred within $524 \mathrm{~m}$ from the potential mosquito habitats. All of the dirofilariosis cases occurred within $1.31 \mathrm{~km}$ from the nearest standing water, river or swamp of the inundation area (Fig. 5).

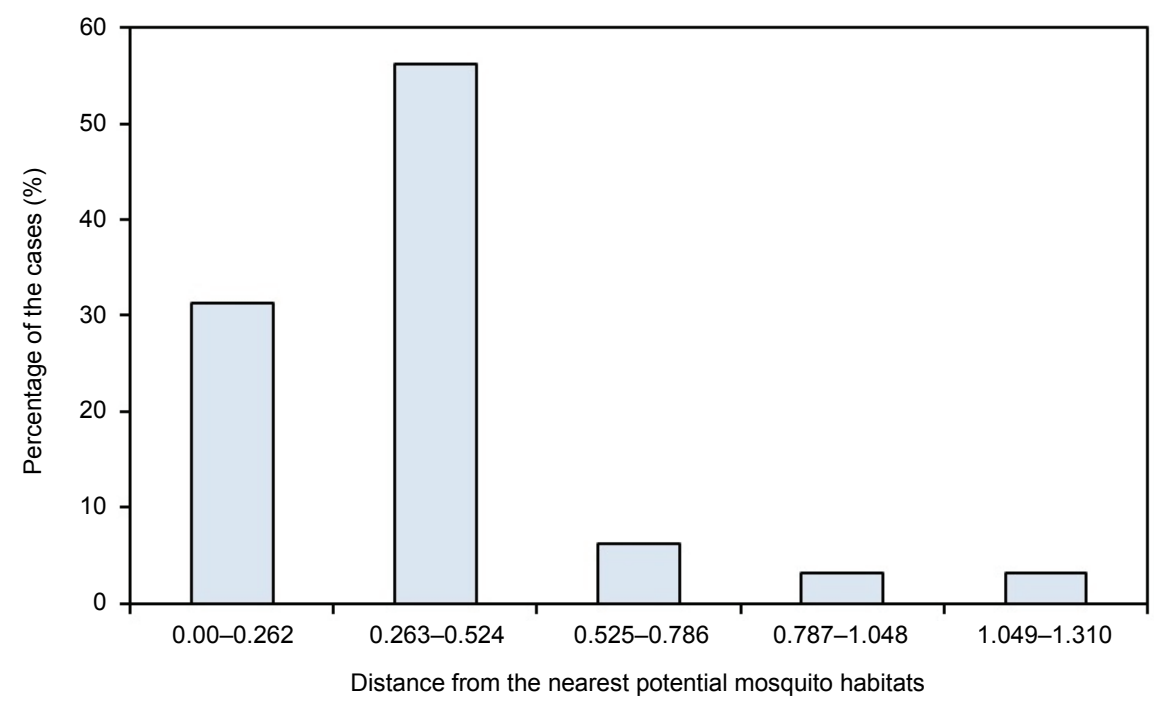

Fig. 5. Histogram of the case sites from the nearest potential mosquito habitat (standing water, floodplain forest, swamp). According to the urbanisation intensity (UI) ranges the numbers of dirofilariosis cases were as follow: $0.000-0.262 \mathrm{~km}: 17$ cases, $0.263-0.524 \mathrm{~km}$ : 31 cases, $0.525-0.786 \mathrm{~km}: 4$ cases, $0.787-1.048 \mathrm{~km}: 2$ cases, $1.049-1.310 \mathrm{~km}: 2$ cases 
The results of the PCA analysis of Szeged show a typical one-centred city with a river passing through the centre and several minor suburban parts. The urbanisation level picture of the city is not symmetrical, since the old town was originally built in the right side of the city according to the direction of the river flow. The level of vegetation is between $1-50 \%$ in the downtown area, which corresponds to the parked landscape of the city. The left column of Fig. 6 shows the spatial patterns of the factors (roads, vegetation and buildings) in Szeged which are considered by the software in the estimation of urbanisation intensity level. The most urbanised areas are mainly restricted to this historical part of Szeged (e.g. square 21 in the right-side picture of Fig. 6). The extended block house zone surrounds the old town from the north and has a high to medium UI value.

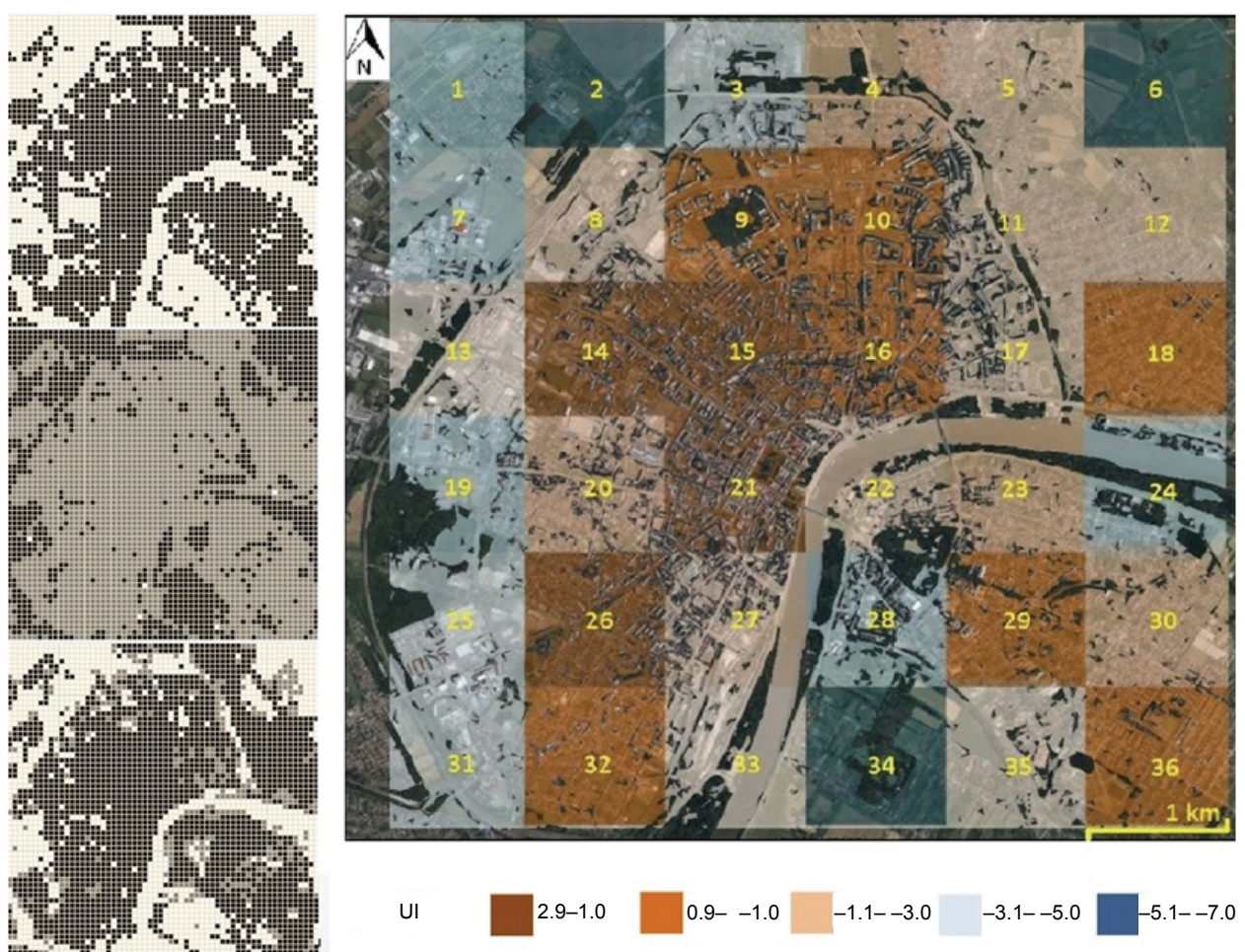

Fig. 6. Left column: the coverage of the three measured parameters: upper: roads, medium: vegetation (and waters), lower: buildings. White square $=$ none, grey square $=<50 \%$, black square $\geq 50 \%$. Right picture: the urbanisation intensity (UI) patterns in Szeged according to $1-\mathrm{km}^{2}$ areal resolution. Case numbers in the depicted cells are as follow: cell 3:2 (D. immitis), 1 (D. repens); cell 4: 3 (D. immitis), 1 (D. repens); cell 9: 1 (D. immitis), 1 (D. repens); cell 10: 2 (D. immitis),

0 (D. repens); cell 14: 1 (D. immitis), 0 (D. repens); cell 16: 1 (D. immitis), 1 (D. repens); cell 20: 1 (D. immitis), 0 (D. repens); cell 21: 0 (D. immitis), 1 (D. repens); cell 30: 1 (D. immitis), 0 (D. repens); cell 31: 1 (D. immitis), 0 (D. repens) and 1 non-specified dirofilariosis; cell 36: 1 (D. immitis), 1 (D. repens) and 1 non-specified dirofilariosis.

Note that grid shown does not cover each of the studied case sites 
The different suburbs have a medium UI value in general. The river Tisza has a narrow floodplain within the city centre with the remnants of the former gallery forest (e.g. squares 24 and 33), which widens toward the edges of the city. According to the results of the two-sample $t$-test there is no significant difference $(\mathrm{P}=0.9210)$ between the variances of the UI of the $D$. immitis and $D$. repens sites. The histographic patterns of the UI values related to the $1 \mathrm{~km}^{2}$ area of the percentage of $D$. immitis and D. repens case sites are somewhat similar to an unimodal frequency peak in case of the UI index interval of $1.45 \pm 0.01$, which corresponds to the urbanised areas of the city. The UI values of the endemic sites except one case showed a transition $(2.9$ to -4.32$)$ between the control vegetation $(<-4.32)$. Some cases were observed also in the downtown areas $(>2.8)$ of Szeged (Fig. 7). The compound probability of the UI and the proximity of the potential mosquito habitats showed the highest potential abundance of canine dirofilariosis cases in the peri-downtown areas where the distance from the closest natural mosquito breeding habitat is less than $800 \mathrm{~m}$ (Fig. 8).

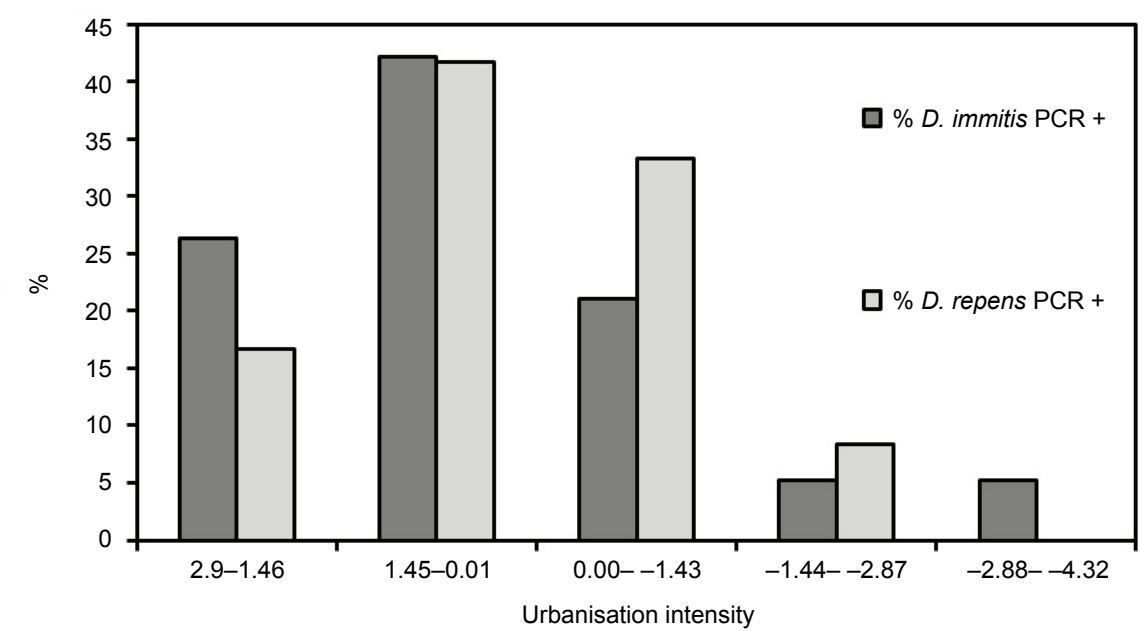

Fig. 7. Histogram of the urbanisation intensity (UI) of the $1-\mathrm{km}^{2}$ area of the case sites of canine dirofilariosis caused by Dirofilaria immitis and Dirofilaria repens. According to the UI ranges the case numbers were as follow: 2.9 to $1.46: 5$ cases, 1.45 to $0.01: 8$ cases, 0.00 to $-1.43: 4$ cases,

-1.44 to -2.87 : 1 case, -2.88 to $-4.32: 1$ case (D. immitis); 2.9 to $1.46: 2$ cases, 1.45 to $0.01: 5$ cases, 0.00 to -1.43 : 4 cases, -1.44 to -2.87 : 1 case, -2.88 to -4.32 : 0 case (D. repens)

\section{Discussion}

This is the first study in Hungary which investigates the affinity of canine dirofilariosis to an urbanised region of temperate Europe. Since D. immitis and D. repens are present in the neighbouring Vojvodina, Serbia (Tasić et al., 2008) and the infected dogs were local pets, it is highly plausible that the infections 
were autochthonous. It was found that $D$. repens is an almost as prevalent causative agent of canine dirofilariosis in Szeged as D. immitis. The rate of coinfection with $D$. immitis and $D$. repens was relatively low (5.7\%), which cannot be explained by the spatial segregation of the abundance of these parasites within the studied area.

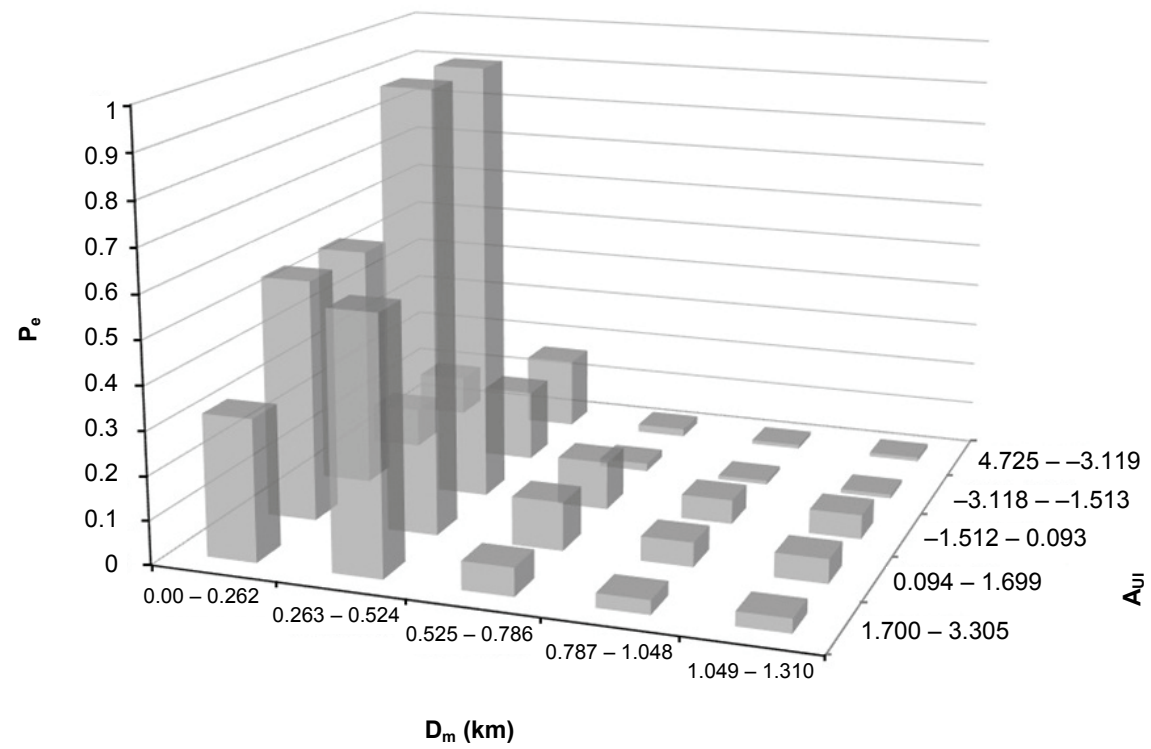

Fig. 8. Matrix and bar chart diagram showing the compound probability of an encounter between the infected mosquito and the susceptible organism $\left(\mathrm{P}_{\mathrm{e}}\right) . A_{U I}$ : abundance of dogs according to the urbanisation intensity of an area, $D_{M}$ : distance from the potential mosquito habitats in $\mathrm{km}$,

$P_{e}$ : compound probability of the encounter of the infected mosquito and the susceptible organism

It is plausible that in the first $D$. immitis infection cases dogs acquired the parasites in the garden due to the very close proximity of an oxbow, but this assumption cannot be generalised. On the other hand, the fact that almost $90 \%$ of the cases occurred within $524 \mathrm{~m}$ from the potential mosquito breeding sites may indicate that dogs were infected in the garden and mainly through bites by local mosquito specimens. The annual case number and the distribution of canine dirofilariosis can be the consequence of several other factors such as the type of the nearest potential mosquito breeding habitats and the presence/absence of wild carnivores (ferrets, foxes or even golden jackals). Different Culicidae species prefer various aquatic habitats and the composition and the total area of waters can change over time in a given area. Human-induced changes have a prolonged impact on habitats suitable for mosquitoes, while the effect of artificial influences can be dissimilar for different mosquito species that have a different vector value in the transmission of Dirofilaria species (Trájer et al., 2015a). 
The flight distance of potential mosquito vector(s) is likely to have an effect on the spatial patterns found. In 2013 a mosquito trapping was performed at the case site of the first dirofilariosis cases in Szeged to detect the potential vectors of $D$. immitis (Zittra et al., 2015). The authors observed the presence of $D$. immitis in Cx. pipiens s. 1. and Ae. caspius. In the same year an independent trapping activity, which was performed at the first case site, confirmed the dominance order and composition of the mosquito fauna (Trájer et al., 2015b). An experimental parasitological study also showed that infection of the Cx. pipiens complex has a notable host efficiency and infective potential for $D$. immitis (Kartman, 1953). In addition, several other studies confirmed the D. immitis vector status of $C x$. pipiens $\mathrm{f}$. pipiens by identification of the non-infective stage of D. immitis in the Cx. pipiens complex (Vezzani et al., 2011) and by detecting the filarioid DNA in the mosquito (Morchón et al., 2007; Yildirim et al., 2011). Members of the $C x$. pipiens complex are very frequent in Hungary and they also prefer several types of aquatic habitats (Kenyeres and Tóth, 2008). Aranda et al. (1998) emphasised the importance of Cx. pipiens f. pipiens in the transmission of filarioid specimens in canine cases. A mark-release-recapture study of $C x$. pipiens f. pallens, the Far Eastern relative of the Cx. pipiens complex, conducted in an urban area of Japan estimated that the mean distance covered by the recaptured females was 287 to 517 m during 1-4 days (Tsuda et al., 2008). The maximum flight distance of Cx. pipiens f. pallens was estimated as $1,217 \mathrm{~m}$. Since the lifespan of adult mosquitoes is usually measured in days, the about $300-500 \mathrm{~m}$ flight distance of host-seeking mosquitoes approximates their average maximum dispersal distance per generation. Naturally, other factors such as wind and human transport can strongly influence the real dispersal rate (Bailey et al., 1965). Since most of the studied dirofilariosis cases occurred within a $524 \mathrm{~m}$ circle of mosquito breeding habitats, it can be concluded that this abundance pattern reflects the influence of the maximum flying distance of mosquitoes.

It is worth noting that the applicability of the method is somewhat limited by the fact that dogs and owners can move around their home, e.g. by dog walking in parks, which may have a non-negligible impact on the observed abundance. Although it cannot be assumed that dogs were stationary with no movement within the city, the model itself does not require or suggest that the observed spatial pattern of the cases depends solely on the flying capability of mosquitoes. On the contrary, the encounter probability of dogs and mosquitoes depends on the movement behaviour of both the vectors and the dogs, and eventually on the behaviour of dog owners. This somewhat contradicts the fact that several members of the above-mentioned $C x$. pipiens complex use artificial waters as breeding sites. One reason may be that a large proportion of mosquitoes occurring in the human environment originally developed in natural waters and not in domestic environment. 
We should mention that advanced Geographical Information Systems (GIS-) based geospatial tools exist for the visualisation, tracking and modelling of the complex, multi-factor-influenced epidemiological processes. Variables such as elevation, land-cover and land-use data, as well as meteorological variables emanating from earth-observing satellites allow the analysis of disease distribution and the changing incidence and prevalence in time and space. Climatebased forecast systems, based on the concept of growing degree days, exist for several parasitic diseases including dirofilariosis (Bergquist and Rinaldi, 2010). The results of a GIS analysis-based model performed for the prediction of the territorial distribution of dirofilariosis caused by $D$. immits in Italy was highly concordant with the real territorial distribution of positive dogs (Mortarino et al., 2008). Rinaldi et al. (2011) proved that information derived from GIS-based descriptive maps provides a well-usable operational tool for planning, monitoring and managing control programmes for Dirofilaria infections. In this view our study confirms the importance of two factors that can be used as basic inputs in GIS-based models.

For the future, our aim is to develop a method which enables us to take account the spatial distribution of causal small waters such as artificial water bodies or puddles. The urbanisation level in the endemic foci is between the PCA value of the most urbanised downtown and the most natural areas. However, it is plausible that the source of the mosquitoes was the very close marsh around the open water body of the paleopotamon. The urban intensity of the case foci indicates that the widespread custom of building holiday houses close to riverbank flood basins in Hungary increases the risk of dirofilariosis.

\section{Acknowledgements}

We thank the Department of Parasitology and Zoology, Faculty of Veterinary Science, Szent István University and Praxislab Ltd. for certain laboratory works.

This research was supported by the projects TÁMOP-4.2.1/B-09/1/KMR-20100005 and TÁMOP 4.2.2.A-1/1/KONV-2012-0064 1.1.

\section{References}

Amoros, C., Roux, A. L., Reygrobellet, J. L., Bravard, J. P. and Pautou, G. (1987): A method for applied ecological studies of fluvial hydrosystems. Regul. Riv.: Res. Manag. 1, 17-36.

Aranda, C., Panyella, O., Eritja, R. and Castellà, J. (1998): Canine filariasis: importance and transmission in the Baix Llobregat area, Barcelona (Spain). Vet. Parasitol. 77, 267-275.

Bailey, S., Eliason, D. and Hoffmann, B. (1965): Flight and dispersal of the mosquito Culex tarsalis Coquillett in the Sacramento Valley of California. Hilgardia 37, 73-113.

Bergquist, R. and Rinaldi, L. (2010): Health research based on geospatial tools: a timely approach in a changing environment. J. Helminthol. 84, 1-11. 
Bókony, V., Kulcsár, A. and Liker, A. (2010): Does urbanization select for weak competitors in house sparrows? Oikos 119, 437-444.

Bókony, V., Kulcsár, A., Tóth, Z. and Liker, A. (2012a): Personality traits and behavioral syndromes in differently urbanized populations of house sparrows (Passer domesticus). PLoS ONE 7, e36639.

Bókony, V., Seress, G., Nagy, Sz., Lendvai, Á. Z. and Liker, A. (2012b): Multiple indices of body condition reveal no negative effect of urbanization in adult house sparrows. Landscape Urban Plan. 104, 75-84.

Boros, G., Janisch, M. and Sebestyén, Gy. (1982): Dirofilaria immitis infection in dogs [in Hungarian, with English abstract]. Magy. Allatorvosok 37, 313-316.

Bowman, D., Little, S. E., Lorentzen, L., Shields, J., Sullivan, M. P. and Carlin, E. P. (2009). Prevalence and geographic distribution of Dirofilaria immitis, Borrelia burgdorferi, Ehrlichia canis, and Anaplasma phagocytophilum in dogs in the United States: results of a national clinic-based serologic survey. Vet. Parasitol. 160, 138-148.

Cancrini, G., Frangipane di Regalbono, A., Ricci, I., Tessarin, C., Gabrielli, S. and Pietrobelli, M. (2003): Aedes albopictus is a natural vector of Dirofilaria immitis in Italy. Vet. Parasitol. 118, 195-202.

Cancrini, G., Magi, M., Gabrielli, S., Arispici, M., Tolari, F., Dell'Omodarme, M. and Prati, M. C. (2006): Natural vectors of dirofilariasis in rural and urban areas of the Tuscan region, central Italy. J. Med. Entomol. 43, 574-579.

Cancrini, G., Pietrobelli, M., Frangipane di Regalbono, A., Tampieri, M. P. and Della Torre, A. (1995): Development of Dirofilaria and Setaria nematodes in Aedes albopictus. Parassitologia 37, 141-145.

Cancrini, G., Scaramozzino, P., Gabrielli, S., Di Paolo, M., Toma, L. and Romi, R. (2007): Aedes albopictus and Culex pipiens implicated as natural vectors of Dirofilaria repens in central Italy. J. Med. Entomol. 44, 1064-1066.

Casiraghi, M., Bazzocchi, C., Mortarino, M., Ottina, E. and Genchi, C. (2006): A simple molecular method for discriminating common filarial nematodes of dogs (Canis familiaris). Vet. Parasitol. 141, 368-372.

Ciferri, F. (1982): Human pulmonary dirofilariasis in the United States: a critical review. Am. J. Trop. Med. Hyg. 31, 302-308.

Czúni, L., Lipovits, A. and Seress, G. (2012): Estimation of urbanization using visual features of satellite images. Proceedings of the AGILE'2012 International Conference on Geographic Information Science, Avignon, 24-27, 233-238.

Di Cesare, A., Castagna, G., Meloni, S., Milillo, P., Latrofa, S., Otranto, D. and Traversa, D. (2011): Canine and feline infections by cardiopulmonary nematodes in central and southern Italy. Parasitol. Res. 109, 87-96.

Farkas, R., Gyurkovszky, M., Lukács, Z., Aladics, B. and Solymosi, N. (2014): Seroprevalence of some vector-borne infections of dogs in Hungary. Vector Borne Zoonotic Dis. 14, 256-260.

Frissell, C. A., Liss, W. J., Warren, C. E. and Hurley, M. D. (1986): A hierarchical framework for stream habitat classification: viewing streams in a watershed context. J. Environ. Manage. 10, 199-214.

Gábor, S., Lipovits, Á., Bókony, V. and Czúni, L. (2014): Quantifying the urban gradient: A practical method for broad measurements. Landscape Urban Plan. 131, 42-50.

Genchi, C., Mortarino, M., Rinaldi, L., Cringoli, G., Traldi, G. and Genchi, M. (2011): Changing climate and changing vector-borne disease distribution: The example of Dirofilaria in Europe. Vet. Parasitol. 176, 295-299.

Genchi, C., Rinaldi, L., Mortarino, M., Genchi, M. and Cringoli, G. (2009): Climate and Dirofilaria infection in Europe. Vet. Parasitol. 163, 286-292.

Hohensinner, S., Jungwirth, M., Muhar, S. and Schmutz, S. (2011): Spatio-temporal habitat dynamics in a changing Danube River landscape 1812-2006. River Res. Appl. 27, 939955. 
Jackson, R. G. II. (1975): Hierarchical attributes and a unifying model of bed forms composed of cohesionless material and produced by shearing flow. Geol. Soc. Am. Bull. 86, 1523-1533.

Jacsó, O. (2014): Prevalence of Dirofilaria spp. in Hungary and veterinary importance, the experience of treatment. PhD Thesis. Faculty of Veterinary Science, Szent István University, Budapest.

Jacsó, O., Mándoki, M., Majoros, G., Pétsch, M., Mortarino, M., Genchi, C. and Fok, É. (2009): First autochthonous Dirofilaria immitis (Leidy, 1856) infection in a dog in Hungary. Helminthologia 46, 159-161.

Jelinek, T., Schulte-Hillen, J. A. N. and Loscher, T. (1996): Human dirofilariasis. Int. J. Dermatol. 35, $872-875$.

Kartman, L. (1953): Factors influencing infection of the mosquito with Dirofilaria immitis (Leidy, 1856). Exp. Parasitol. 2, 27-78.

Kenyeres, Z. and Tóth, S. (2008): Identification Keys to Mosquitoes II. Bulletins of Pannonia 2. Keszthely, Hungary. ISSN: 1788-9030.

Kern, K. (1994): Grundlagen naturnaher Gewässergestaltung: Geomorphologische Entwicklung von Fließgewässern. Springer-Verlag, Berlin.

KSH (2013): Central Statistical Office, 2011 Census, third spatial data, 3.6. Csongrád county, Szeged. 260 pp. http://www.ksh.hu/docs/hun/xftp/idoszaki/nepsz2011/nepsz_03_06_2011.pdf

Kucsera, I., Danka, J. and Orosz, E. (2014): Human dirofilariosis in Hungary [in Hungarian]. Epinfo 24, 273-277.

Labarthe, N., Serrão, M. L., Melo, Y. F., Oliveira, S. J. D. and Lourenço-de-Oliveira, R. (1998): Potential vectors of Dirofilaria immitis (Leidy, 1856) in Itacoatiara, oceanic region of Niterói municipality, State of Rio de Janeiro, Brazil. Mem. Inst. Oswaldo Cruz 93, 425-432.

Liker, A., Papp, Z., Bókony, V. and Lendvai, Á. Z. (2008): Lean birds in the city: body size and condition of house sparrows along the urbanization gradient. J. Anim. Ecol. 77, 789-795.

Lowry, R. (2004): VassarStats: Website for statistical computation. Vassar College. http://vassarstats.net/

Ludlam, K. W., Jachowski, L. A. and Otto, G. F. (1970): Potential vectors of Dirofilaria immitis. J. Am. Vet. Med. Assoc. 157, 1354-1359.

Macêdo, F. C. D., Labarthe, N. and Lourenço-de-Oliveira, R. (1998): Susceptibility of Aedes scapularis (Rondani, 1848) to Dirofilaria immitis (Leidy, 1856), an emerging zoonosis. Mem. Inst. Oswaldo Cruz 93, 435-437.

Merrill, J. R., Otis, J., Logan, W. D. and Davis, M. B. (1980): The dog heartworm (Dirofilaria immitis) in man: An epidemic pending or in progress? JAMA 243, 1066-1068.

Moorhouse, D. E. (1978): Dirofilaria immitis: A cause of human intra-ocular infection. Infection 6, 192-193.

Morchón, R., Bargues, M. D., Latorre, J. M., Melero-Alcíbar, R., Pou-Barreto, C., Mas-Coma, S. and Simón, F. (2007): Haplotype H1 of Culex pipiens implicated as natural vector of Dirofilaria immitis in an endemic area of Western Spain. Vector Borne Zoonotic Dis. 7, 653-658.

Morchón, R., Carretón, E., González-Miguel, J. and Mellado-Hernández, I. (2012): Heartworm disease (Dirofilaria immitis) and their vectors in Europe - new distribution trends. Front. Physiol. 3, 196.

Mortarino, M., Musella, V., Costa, V., Genchi, C., Cringoli, G. and Rinaldi, L. (2008): GIS modeling for canine dirofilariosis risk assessment in central Italy. Geospat. Health 2, 253-261.

Muro, A., Genchi, C., Cordero, M. and Simon, F. (1999): Human dirofilariasis in the European Union. Parasitol. Today 15, 386-389.

Newbury, R. W. (1996): Dynamics of flow. In: Hauer, F. R. and Lamberti, G. A. (eds) Methods in Stream Ecology. Academic Press, San Diego. pp. 75-92.

Newton, W. L. and Wright, W. H. (1956): The occurrence of a dog filariid other than Dirofilaria immitis in the United States. J. Parasitol. 42, 246-258. 
Pampiglione, S., Elek, G., Pálfi, P., Vetési, F. and Varga, I. (1999): Human Dirofilaria repens infection in Hungary: a case in the spermatic cord and a review of the literature. Acta Vet. Hung. 47, 77-83.

Pampiglione, S., Rivasi, F., Angeli, G., Boldorini, R., Incensati, R. M., Pastormerlo, M., Pavesi, M. and Ramponi, A. (2001): Dirofilariasis due to Dirofilaria repens in Italy, an emergent zoonosis: report of 60 new cases. Histopathology 38, 344-354.

Pampiglione, S., Rivasi, F. and Gustinelli, A. (2009): Dirofilarial human cases in the Old World, attributed to Dirofilaria immitis: a critical analysis. Histopathology 54, 192-204.

Pascucci, I., Fico, R., D’Angelo, A. R., Serini, S. and Cammà, C. (2007): First notification in Italy of cardiopulmonary filariosis (heartworm disease) in a wolf (Canis lupus). Vet. Ital. 43, $843-850$.

Petts, G. E. and Amoros, C. (eds) (1996): Fluvial Hydrosystems. Chapman \& Hall, London.

Raccurt, C. P. (1999): Dirofilariasis, emerging and underestimated zoonoses in France. Med. Trop. (Mars.) 59, 389.

Rawlings, C. A., Raynaud, J. P., Lewis, R. E. and Duncan, J. R. (1993): Pulmonary thromboembolism and hypertension after thiacetarsamide vs. melarsomine dihydrochloride treatment of Dirofilaria immitis infection in dogs. Am. J. Vet. Res. 54, 920-925.

Rinaldi, L., Genchi, C., Musella, V., Genchi, M. and Cringoli, G. (2011): Geographical information systems as a tool in the control of heartworm infections in dogs and cats. Vet. Parasitol. 176, 286-290.

Seress, G., Bókony, V., Heszberger, J. and Liker, A. (2011): Response to predation risk in urban and rural house sparrows. Ethology 117, 896-907.

Simón, F., López-Belmonte, J., Marcos-Atxutegi, C., Morchón, R. and Martín-Pacho, J. R. (2005): What is happening outside North America regarding human dirofilariasis? Vet. Parasitol. 133, 181-189.

Simón, F., Siles-Lucas, M., Morchón, R., González-Miguel, J., Mellado, I., Carretón, E. and Montoya-Alonso, J. A. (2012): Human and animal dirofilariasis: the emergence of a zoonotic mosaic. Clin. Microbiol. Rev. 25, 507-544.

Szénási, Z., Kovács, A. H., Pampiglione, S., Fioravanti, M. L., Kucsera, I., Tánczos, B. and Tiszlavicz, L. (2008): Human dirofilariasis in Hungary: an emerging zoonosis in central Europe. Wien. Klin. Wochenschr. 120, 96-102.

Tasić, A., Rossi, L., Tasić, S., Miladinović-Tasić, N., Ilić, T. and Dimitrijević, S. (2008): Survey of canine dirofilariasis in Vojvodina, Serbia. Parasitol. Res. 103, 1297-1302.

Tasić-Otašević, S. A., Božinović, M. S. T., Gabrielli, S. V. and Genchi, C. (2015): Canine and human Dirofilaria infections in the Balkan Peninsula. Vet. Parasitol. 209, 151-156.

Tesh, E. K. (1989): Culex tritaeniorhynchus and Aedes albopictus (Diptera: Culicidae) as natural vectors of Dirofilaria immitis (Spirurida: Filariidae) in Miki City, Japan. J. Med. Entomol. 26, 294-300.

Theis, J. H., Gilson, A., Simon, G. E., Bradshaw, B. and Clark, D. (2001): Case report: Unusual location of Dirofilaria immitis in a 28 -year-old man necessitates orchiectomy. Am. J. Trop. Med. Hyg. 64, 317-322.

Tímár, G., Molnár, G., Székely, B., Biszak, S. and Jankó, A. (2008): Topographic map of Hungary during the period of the Second World War [in Hungarian]. Arcanum Adatbázis Kiadó, Budapest. ISBN: 978-963-73747-1-5.

Tóth, S. (2004): Mosquito (Diptera: Culicidae) Fauna of Hungary [in Hungarian]. Nat. Somogy 6, $1-327$.

Tóth, S. and Kenyeres, Z. (2012): Revised checklist and distribution maps of mosquitoes (Diptera, Culicidae) of Hungary. Europ. Mosq. Bull. 30, 30-65.

Traversa, D., Aste, G., Milillo, P., Capelli, G., Pampurini, F., Tunesi, C., Santori, D., Paoletti, B. and Boari, A. (2010a): Autochthonous foci of canine and feline infections by Dirofilaria immitis and Dirofilaria repens in central Italy. Vet. Parasitol. 169, 128-132. 
Traversa, D., Di Cesare, A. and Conboy, G. (2010b): Canine and feline cardiopulmonary parasitic nematodes in Europe: emerging and underestimated. Parasit. Vectors 3, 62.

Trájer, A., Farkas-Iványi, K. and Padisák, J. (2015a): Area-based historical modeling of the effects of the river bank regulation on the potential abundance of eleven mosquito species in the River Danube between Hungary and Slovakia. Adv. Oceanogr. Limnol. 6, 1/2.

Trájer, A., Hammer, T. and Rengei, A. (2015b): Trapping blood-feeding mosquitoes (Diptera: Culicidae) in the first lethal canine dirofilariasis site in Szeged, Hungary. Folia Entomol. Hung. 76, 251-258.

Tsuda, Y., Komagata, O., Kasai, S., Hayashi, T., Nihei, N., Saito, K., Mizutani, M., Kunida, M., Yoshida, M. and Kobayashi, M. (2008): A mark-release-recapture study on dispersal and flight distance of Culex pipiens pallens in an urban area of Japan. J. Am. Mosq. Control Assoc. 24, 339-343.

Vezzani, D., Mesplet, M., Eiras, D. F., Fontanarrosa, M. F. and Schnittger, L. (2011): PCR detection of Dirofilaria immitis in Aedes aegypti and Culex pipiens from urban temperate Argentina. Parasitol. Res. 108, 985-989.

Webber, W. A. and Hawking, F. (1955): Experimental maintenance of Dirofilaria repens and D. immitis in dogs. Exp. Parasitol. 4, 143-164.

Yildirim, A., Inci, A., Duzlu, O., Biskin, Z., Ica, A. and Sahin, I. (2011): Aedes vexans and Culex pipiens are the potential vectors of Dirofilaria immitis in Central Turkey. Vet. Parasitol. 178, 143-147.

Zhang, S., Lei, F., Liu, S., Li, D., Chen, C. and Wang, P. (2011): Variation in baseline corticosterone levels of Tree Sparrow (Passer montanus) populations along an urban gradient in Beijing, China. J. Ornithol. 152, 801-806.

Zittra, C., Kocziha, Zs., Pinnyei, Sz., Harl, J., Kieser, K., Laciny, A., Eigner, B., Silbermayr, K., Duscher, G. G., Fok, É. and Fuehrer, H.-P. (2015): Screening blood-fed mosquitoes for the diagnosis of filarioid helminths and avian malaria. Parasit. Vectors 8, 1-6. 